\title{
Chronic eosinophilic pneumonia progressing to lung fibrosis
}

\author{
K. Yoshida*, N. Shijubo*, H. Koba*, Y. Mori++, M. Satoh**, T. Morikawa ${ }^{+}$, S. Abe*
}

Chronic eosinophilic pneumonia progressing to lung fibrosis. K. Yoshida, N. Shijubo, H. Koba, Y. Mori, M. Satoh, T. Morikawa, S. Abe. CERS Journals Ltd 1994.

ABSTRACT: A 65 year old Japanese man was hospitalized with fever. Opacities distributed mainly in the subpleural regions were found on chest computed tomographic scan (CT), and these promptly cleared with corticosteroid therapy.

Four years later, he presented with severe eosinophilia. Both chest X-ray and high resolution CT scan showed ground-glass opacities and honeycombing, suggesting lung fibrosis. A lung biopsy demonstrated intra-alveolar eosinophil infiltration, interstitial thickening with eosinophil infiltration, and a widely-distributed desquamative interstitial pneumonia-like reaction. With corticosteroid therapy, the ground-glass opacities decreased with a corresponding clinical improvement, although lung honeycombing and blood eosinophilia remained.

In this case, circulating intercellular adhesion molecule-1 and circulating and bronchoalveolar lavage fluid eosinophil granule proteins were felt to be more effective markers for evaluating disease activity than the blood eosinophil number. Eur Respir J., 1994, 7, 1541-1544.
*Third Dept of Internal Medicine and **Division of Clinical Pathology, Sapporo Medical University School of Medicine, Sapporo, Japan. +Division of Surgery, Hokkaido Keiaikai Minami Ichijo Hospital, Sapporo, Japan. ++Division of Respiratory Medicine, Hakodate Goryokaku Hospital, Hakodate, Japan.

Correspondence: N. Shijubo, Third Dept of Internal Medicine, Sapporo Medical University School of Medicine, South-1, West-16, Chuo-ku, Sapporo 060, Japan.

Keywords: Chronic eosinophilic pneumonia, circulating intercellular adhesion molecule-1, desquamative interstitial pneumonia, eosinophilic cationic protein, lung fibrosis, major basic protein.

Received: September 71993

Accepted after revision March 161994
Idiopathic chronic eosinophilic pneumonia (CEP) is a rare disorder, characterized by systemic and pulmonary manifestations, blood eosinophilia, fluffy peripheral opacities on chest X-ray, and a prompt response to corticosteroid therapy [1-3]. Histological studies of CEP show an intra-alveolar exudate of eosinophils, histiocytes and occasionally amorphous material, and eosinophilic interstitial infiltration [1,3-5]. Although focal areas of interstitial fibrosis are occasionally found in CEP, the alveolar septa are usually intact and interstitial fibrosis is minimal [4-6]. We report on a case of CEP progressing to lung fibrosis.

\section{Case report}

A 65 year old Japanese man, who had been a sailor until 60 yrs of age, was hospitalized in September 1989 with fever. He had not received any drugs for the past $2 \mathrm{yrs}$, and he had smoked one pack of cigarettes daily for 50 years. The leucocyte count was $12.3 \times 10^{9} \cdot l^{-1}$ with $3 \%$ eosinophils. Chest X-ray showed infiltrative opacities and chest computed tomographic (CT) scan (10 mm thick slices) demonstrated opacities distributed mainly in the subpleural regions (fig. 1). Corticosteroid therapy (dexamethasone, $4 \mathrm{mg}$ daily) was prescribed, from September 9, 1989, and the opacities promptly decreased. Corticosteroid therapy was progressively reduced and stopped on October 3, 1989, and the patient remained asymptomatic.

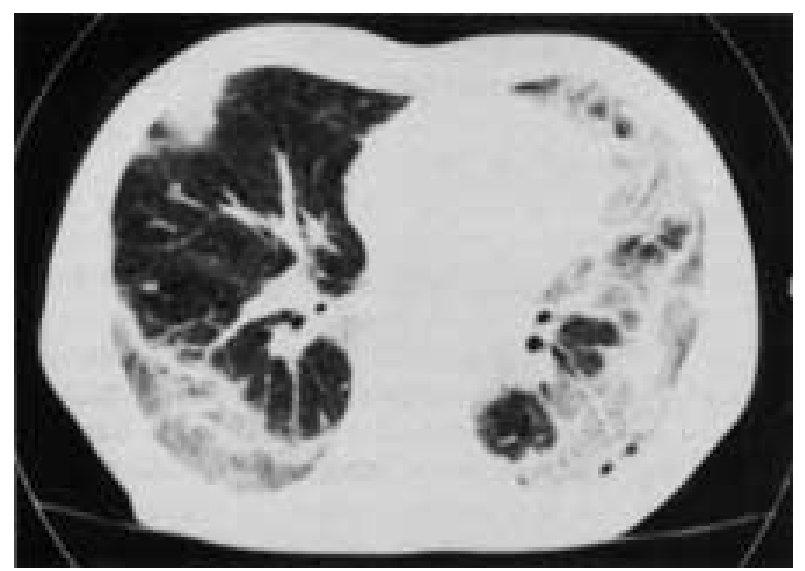

Fig. 1. - Chest computed tomographic scan (CT) (10 mm thick slices) on first admission, showing opacities distributed mainly in the subpleural regions in bilateral lungs.

The patient was referred to us again in February 1993, complaining of fever, productive cough, and dyspnoea on exertion of 3 months duration. He had received no new drugs since October 1989. On admission he had intermittent fever $\left(37.6-38.4^{\circ} \mathrm{C}\right)$. Fine crackles were present but no wheezes or cardiac murmurs were heard. The patient had finger clubbing, physical examination was otherwise normal. Chest X-ray showed reticulonodular opacities in both lung fields, and high resolution CT (1.5 mm thick slices) showed ground-glass opacities and honeycombing (fig. 2). 


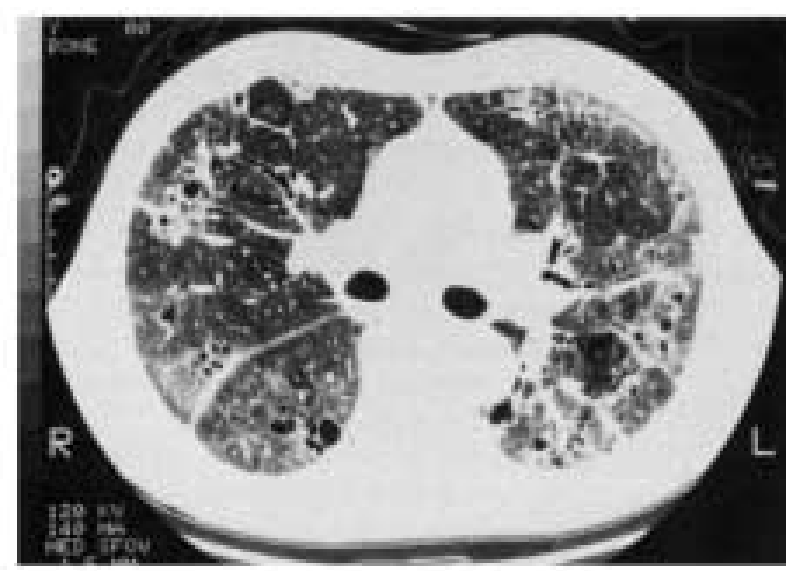

b

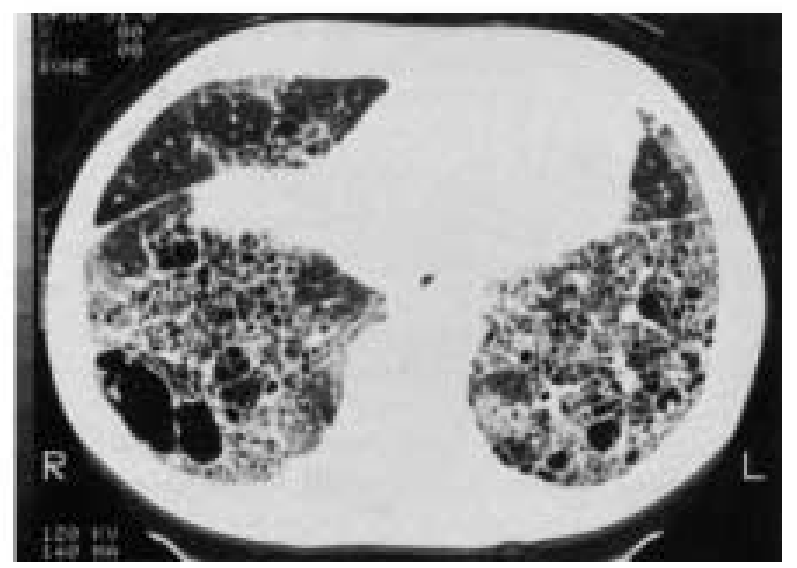

Fig. 2. - High resolution computed tomographic scan (CT) $(1.5 \mathrm{~mm}$ thick slices) of the chest on second admission showing: a) groundglass opacities; and b) honeycombing.

Laboratory data were remarkable for leucocyte count $17.4 \times 10^{9} \cdot l^{-1}$ with $57 \%$ eosinophils; erythrocyte sedimentation rate (ESR) $58 \mathrm{~mm} \cdot \mathrm{h}^{-1}$; C-reactive protein (CRP) $6.59 \mathrm{mg} \cdot \mathrm{dl}^{-1}$; and lactate dehydrogenase $(\mathrm{LDH}) 679 \mathrm{IU} \cdot \mathrm{ml}^{-1}$ (normal range 190-440 IU $\cdot \mathrm{ml}^{-1}$ ). Serum immunoglobulin levels were: immunoglobulin $\mathrm{G}(\mathrm{IgG}) 22.18 \mathrm{mg} \cdot \mathrm{ml}^{-1}$; immunoglobulin A $(\operatorname{IgA}) 3.45 \mathrm{mg} \cdot \mathrm{ml}^{-1}$; immunoglobulin $\mathrm{M}(\mathrm{IgM}) 0.83 \mathrm{mg} \cdot \mathrm{ml}^{-1}$; and immunoglobulin $\mathrm{E}(\mathrm{IgE})$ $8.8 \mathrm{IU} \cdot \mathrm{ml}^{-1}$. Antinuclear antibody titre was $\times 80$ with a speckled pattern: anti-deoxyribonucleic acid (DNA), antiextractable nuclear antigen (ENA), anti-ribonucleoprotein, and anti-Sm antibodies were negative. Concentrations of soluble intercellular adhesion molecule-1 (ICAM-1) $\left(656 \mathrm{ng} \cdot \mathrm{ml}^{-1}\right)$, major basic protein (MBP) $\left(2,834 \mathrm{ng} \cdot \mathrm{ml}^{-1}\right)$, and eosinophil cationic protein (ECP) $\left(318 \mathrm{ng} \cdot \mathrm{ml}^{-1}\right)$ in the circulation were prominently increased (table 1), which were measured as described previously [7-9]. Results of tests for acid-fast bacilli and fungi in sputum, for parasites in stools and for antibodies to Cryptococcus neoformans, Aspergillus fumigatus, A. niger, Micropolyspora faeni, Thermoactinomyces vulgaris, $T$. viridis and Alternaria in serum were negative. Pulmonary function tests showed a decrease in carbon monoxide dif- fusing capacity: total lung capacity (TLC) $5.38 l(105 \%$ pred); vital capacity (VC) $3.42 l$ (105\% pred); forced expiratory volume in one second $\left(\mathrm{FEV}_{1}\right) 2.59 l(78 \%$ pred); diffusing capacity of the lung for carbon monoxide (DLCO) $8.81 \mathrm{ml} \cdot \mathrm{min}^{-1} \cdot \mathrm{mmHg}^{-1}$ (40\% pred); and DLCo/alveolar volume (VA), $2.01 \mathrm{ml} \cdot \mathrm{min}^{-1} \cdot \mathrm{mmHg}^{-1} \cdot l^{-1}$. Arterial blood gas analysis showed that arterial oxygen tension $\left(\mathrm{PaO}_{2}\right)$ was $8.1 \mathrm{kPa}(60.7 \mathrm{mmHg})$ and arterial carbon dioxide tension $\left(\mathrm{PaCO}_{2}\right)$ was $4.4 \mathrm{kPa}(33.1 \mathrm{mmHg})$ whilst breathing room air.

Examination of cardiac and abnormal echogram, abdominal CT scan, gallium scan, fibreoptic gastroscope, and of ophthalmological examinations was normal. Bone marrow aspiration examination showed increased eosinophils, (11.2\%). The results of bronchoalveolar lavage (BAL) in right middle lobe were: total cell count $4.5 \times 10^{5}$ $\mathrm{ml}^{-1}$; and differential cell count: alveolar macrophages 42.6\%; lymphocytes $7.3 \%$; neutrophils $2.8 \%$; and eosinophils 47.3\%. MBP and ECP concentrations in BAL fluid were 12.0 and $2.7 \mathrm{ng} \cdot \mathrm{ml}^{-1}$, respectively (table 1 ). Lung biopsy was performed in the posterior segment of the right upper lobe, under thoracoscopy. Histological study revealed intra-alveolar and interstitial infiltration by eosinophils, and widely-distributed features suggesting desquamative interstitial pneumonia (DIP): alveolar septal thickening, hyperplasia of pneumocytes, and an increased number of intra-alveolar macrophages (fig. 3). No evidence of vasculitis was observed. Special staining and culture for acid-fast bacilli and fungi were negative. The patient was administered corticosteroid therapy (prednisolone, $30 \mathrm{mg}$ daily) beginning March 31, 1993, and during the next week his symptoms markedly improved. The groundglass opacities on CT images were gradually reduced, with

Table 1. - Laboratory data before and after corticosteroids (CS)

\begin{tabular}{|c|c|c|}
\hline & Before CS & After CS \\
\hline \multicolumn{3}{|l|}{ Blood } \\
\hline $\mathrm{WBC} \times 10^{9} \cdot l^{-1}$ & 17.4 & 19.8 \\
\hline Eosinophil $\times 10^{9} \cdot l^{-1}$ & 9.9 & 9.1 \\
\hline ESR $\mathrm{mm} \cdot \mathrm{h}^{-1}$ & 58 & 9 \\
\hline $\mathrm{CRP} \mathrm{mg} \cdot \mathrm{dl}^{-1}$ & 6.59 & $<0.25$ \\
\hline LDH IU $\cdot l^{-1}$ & 679 & 311 \\
\hline $\mathrm{MBP}^{*} \mathrm{ng} \cdot \mathrm{ml}^{-1}$ & 2,834 & 1,468 \\
\hline $\mathrm{ECP} * \mathrm{ng} \cdot \mathrm{ml}^{-1}$ & 318 & 85.9 \\
\hline $\mathrm{sICAM}-1 * \mathrm{ng} \cdot \mathrm{ml}^{-1}$ & 656 & 106 \\
\hline \multicolumn{3}{|c|}{ Bronchoalveolar lavage } \\
\hline TCC $10^{5} \cdot \mathrm{ml}^{-1}$ & 4.5 & 4.4 \\
\hline Eosinophil \% & 47.3 & 10.3 \\
\hline $\mathrm{MBP}^{*} \mathrm{ng} \cdot \mathrm{ml}^{-1}$ & 12 & $<4.4$ \\
\hline $\mathrm{ECP}^{*} \mathrm{ng} \cdot \mathrm{ml}^{-1}$ & 2.7 & $<2.0$ \\
\hline
\end{tabular}

The samples in the circulation and in BAL fluid were obtained at 54 days and 26 days after initiation of corticosteroid therapy, respectively. WBC: white blood cell count; ESR: erythrocyte sedimentation rate; CRP: C-reactive protein; LDH: lactate dehydrogenase; MBP: major basic protein; ECP: eosinophil cationic protein; sICAM-1: soluble intercellular adhesion molecule-1; TCC: total cell count; *: normal levels of circulating MBP, ECP and sICAM-1 were $<600 \mathrm{ng} \cdot \mathrm{ml}^{-1}(\mathrm{n}=54), 2.2-16.9 \mathrm{ng} \cdot \mathrm{ml}^{-1} \quad(\mathrm{n}=54)$ and $53-153 \mathrm{ng} \cdot \mathrm{ml}^{-1}(\mathrm{n}=48)$, respectively. Levels of MBP and ECP in BAL fluids obtained from six normal controls were $<4.4 \mathrm{ng} \cdot \mathrm{ml}^{-1}$ and $<2.0 \mathrm{ng} \cdot \mathrm{ml}^{-1}$, respectively. 

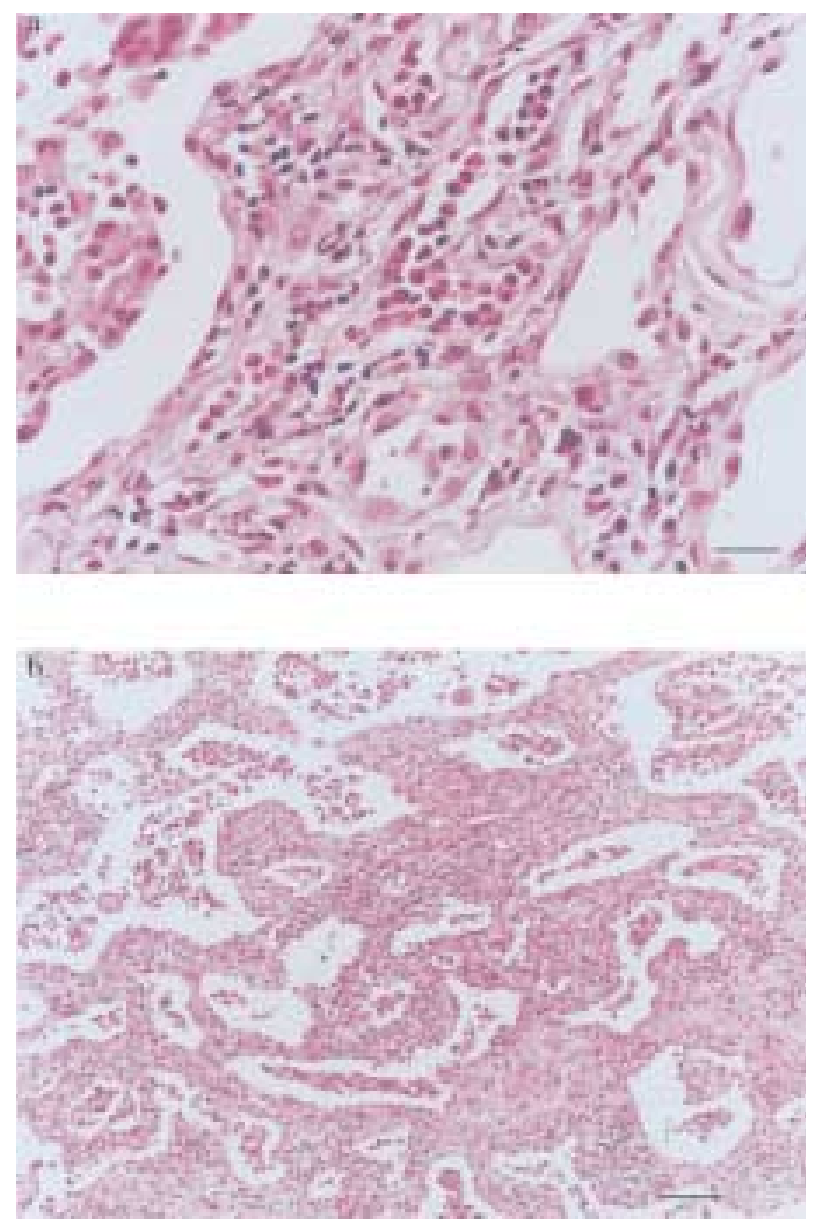

Fig. 3. - Microphotographs from a lung biopsy specimen showing: a) intra-alveolar and interstitial infiltration by eosinophils; and b) widelydistributed features suggesting desquamative interstitial pneumonia: an increased number of intra-alveolar macrophages, hyperplasia of pneumocytes, and interstitial thickening. (Haematoxylin-eosin staining. Bar: a) $100 \mu \mathrm{m}$ and b) $25 \mu \mathrm{m}$.

a corresponding improvement in blood tests (May 24: ESR $9 \mathrm{~mm} \cdot \mathrm{h}^{-1}$; CRP $<0.25 \mathrm{mg} \cdot \mathrm{dl}^{-1}$; LDH $311 \mathrm{IU} \cdot \mathrm{ml}^{-1}$; and circulating ICAM-1 $\left.106 \mathrm{ng} \cdot \mathrm{ml}^{-1}\right)$, whilst blood eosinophil count $\left(9.1 \times 10^{9} \cdot l^{-1}\right)$ circulating $\operatorname{MBP}\left(1,468 \mathrm{ng} \cdot \mathrm{ml}^{-1}\right)$ and ECP concentrations $\left(85.9 \mathrm{ng} \cdot \mathrm{ml}^{-1}\right)$ were still high. Eosinophil count $(10.3 \%), \mathrm{MBP}\left(<4.4 \mathrm{pg} \cdot \mathrm{ml}^{-1}\right)$ and ECP concentrations $\left(<2.0 \mathrm{pg} \cdot \mathrm{ml}^{-1}\right)$ were decreased in BAL fluid (April 26). The dosage of prednisolone was gradually reduced to $10 \mathrm{mg}$ daily in December, 1993. At that time, laboratory tests showed the following: leucocyte count $15.1 \times 10^{9} \cdot l^{-1}$ with $12 \%$ eosinophils: ESR $12 \mathrm{~mm} \cdot \mathrm{h}^{-1}$; CRP $0.30 \mathrm{mg} \cdot \mathrm{dl}^{-1}$; circulating MBP $752 \mathrm{ng} \cdot \mathrm{ml}^{-1}$; circulating ECP $38.6 \mathrm{ng} \cdot \mathrm{ml}^{-1}$; and circulating ICAM-1 $98 \mathrm{ng} \cdot \mathrm{ml}^{-1}$. The ground-glass opacities were greatly reduced on chest CT images, but the honeycombing still remained.

\section{Discussion}

The main causes of pulmonary infiltrates with blood eosinophilia are: drug reaction; mycobacterial, fungal and parasitic infections; vasculitides Churg-Strauss syndrome; inflammatory airway diseases, such as allergic bronchopulmonary aspergillosis; idiopathic CEP; and idiopathic hypereosinophilic syndrome (HES) [6, 10]. Idiopathic CEP is a clinicopathologic entity characterized by systemic and pulmonary manifestations, such as fever, weight loss, cough, dyspnoea, blood eosinophilia, peripheral opacities on chest X-ray, and a prompt response to corticosteroid therapy [1-3] . Idiopathic HES is also a clinical disease entity of unknown aetiology characterized by severe eosinophilia and a range of clinical problems, including cardiovascular, thromboembolic, respiratory, skin and/or nervous system complications [11, 12]. External causes of eosinophilia, such as drug reaction and infections, were ruled out in this patient, and vasculitis was not found histologically. Since blood eosinophilia persisted even after corticosteroid therapy, we considered that the patient might have either CEP or HES. However, whole body examinations including cardiac, neurological, dermatological and ophthalmological examinations were normal, thus ruling out HES.

This case presented an unusual clinical course. In 1989, the patient had opacities distributed mainly in the subpleural regions on chest CT images, and a prompt response to corticosteroid therapy. There was no information on pulmonary eosinophilia, since BAL was not performed. However, the presentation was compatible with CEP without blood eosinophilia, as CARRINGTON et al. [1] originally described that some patients with CEP had low eosinophil count in the circulation. In 1993, this case had striking pulmonary and blood eosinophilia and honeycombing on high resolution CT images, suggesting lung fibrosis [13]. In CEP, histological findings are characterized by interstitial and intra-alveolar infiltrates with activated eosinophils in various stages of degranulation [1, 3-6]. It has been reported that the alveolar septa are usually intact and fibrosis is minimal in CEP, despite extensive cellular infiltration [4-6]. There have been very few reports on CEP with lung fibrosis: JEDERLINIC et al. [3] reported that one of 19 cases with CEP had linear fibrotic changes on chest X-ray. In our patient, a lung biopsy under thoracoscopy demonstrated intra-alveolar and interstitial infiltration by eosinophils and a widely-distributed DIP-like reaction. A focal DIPlike reaction is usually found in CEP [14], and DIP itself causes only very minor infiltration of eosinophils in the alveolar septa and intra-alveolar spaces [15]. This patient's longstanding repeated episodes of CEP may have much to do with his progression to lung fibrosis. He might have had mild episodes of CEP before the initial presentation in 1989. Persistent stimulation from activated eosinophils could be related to progression to lung fibrosis, since eosinophil granule proteins play an important role during the process of endomyocardial fibrosis in HES [16].

To assess the disease activity, we analysed concentrations of soluble ICAM-1, MBP, and ECP in the circulation, and of MBP and ECP in BAL fluids. Circulating ICAM-1 concentrations seem to reflect a specific mix of production of cytokines, including tumour necrosis factoralpha and interferon-gamma [17]. Prominently increased concentrations of circulating ICAM-1 are found in 
idiopathic pulmonary fibrosis [7], and far advanced tuberculosis [17], and may reflect the disease activity of these disorders. MBP and ECP levels reflect the number of activated (secreted) eosinophils $[8,9,16,18,19]$. They appear to be useful markers for understanding and management of eosinophil-associated diseases, since their concentrations in blood or local fluids may, in many cases, uniquely reflect the ongoing disease process [16]. On second admission, the patient had quite high concentrations of soluble ICAM-1, MBP and ECP in serum compared to healthy controls, as well as of MBP and ECP in BAL fluid. After corticosteroid therapy, the concentrations of circulating ICAM-1 and BAL fluid MBP and ECP had decreased to normal limits; and although circulating MBP and ECP concentrations remained high, they had also remarkably decreased, suggesting that activation of eosinophils had been greatly reduced by corticosteroid therapy. We feel that these serum markers have proved to be more useful for evaluating the disease activity than blood eosinophil number in this case.

The response of this patient's blood eosinophilia to therapy was quite sluggish during the period of low dosage corticosteroid therapy, although the therapy was effective for his pulmonary eosinophilia. Circulating eosinophils at 54 days after initiation of therapy were activated, since circulating MBP and ECP concentrations remained elevated. By contrast, BAL MBP and ECP decreased with therapy. In this case, the low dosage of corticosteroid resulted in a distinct decrease of MBP and ECP in the blood and in the lung, a surprising finding that we cannot explain.

\section{References}

1. Carrington $\mathrm{CB}$, Addington WW, Goff AM, et al. Chronic eosinophilic pneumonia. N Engl J Med 1969; 280: 787-798.

2. Gaensler EA, Carrington CB. Peripheral opacities in chronic eosinophilic pneumonia: the photographic negative of pulmonary edema. Am J Roentogenol 1977; 128: 1-13.

3. Jederlinic PJ, Sicilian L, Gaensler EA. Chronic eosinophilic pneumonia: a report of 19 cases and a review of the literature. Medicine 1988; 67: 154-162.

4. Gonzalez EB, Swedo JL, Rajaraman S, Daniels JC, Grant JA. Ultrastructural and immunohistochemical evidence for release of eosinophilic granules in vivo: cytotoxic potential in chronic eosinophilic pneumonia. J Allergy Clin Immunol 1987; 79: 755-762.

5. Quinonez GE, Simon GT, Kay JM. Electron microscopy of chronic eosinophilic pneumonia. Clin Invest Med 1986; 9: 238-243.

6. Lopez M, Salvaggio JE. Eosinophilic pneumonia. In: Lynch III JP, DeRemee RA, eds. Immunologically-mediated pulmonary diseases. Philadelphia, JB Lippincott, 1991; pp. 413-431.

7. Shijubo N, Imai K, Aoki S, et al. Circulating intercellular adhesion molecule-1 (ICAM-1) antigen in sera of patients with idiopathic pulmonary fibrosis. Clin Exp Immunol 1992; 89: 58-62.

8. Venge P, Roxin LE, Olsson I. Radioimmunoassay of human eosinophil cationic protein. Br J Haematol 1977; 37: 331-335.

9. Gleich GJ, Loegering DA, Kueppers F, Bajaj SP, Mann KG. Physicochemical and biological properties of the major basic protein from guinea-pig eosinophil granules. J Exp Med 1974; 140: 313-332.

10. Watters LC. Chronic alveolar filling disease. In: Schwarz MI, King TE, eds. Interstitial Lung Disease (2nd edn). St. Louis, Mosby Year Book Inc., 1993; pp. 309-366.

11. Fauci AS, Harley JB, Roberts WC, Ferrans VJ, Gralnick HR, Bjornson BH. The idiopathic hypereosinophilic syndrome: clinical, pathophysiologic and therapeutic conditions. Ann Intern Med 1982; 97: 78-92.

12. Spry CJF. The hypereosinophilic syndrome: clinical feature, laboratory findings and treatment. Allergy 1982; 37: 539-551.

13. Müller NL, Miller RR, Webb WR, Evans KG, Ostrow DN. Fibrosing alveolitis: CT-pathologic correlation. Radiology 1986; 160: 585-588.

14. Colby TV. Anatomical distribution and histopathologic patterns in interstitial lung disease. In: Schwarz MI, King TE, eds. Interstitial Lung Disease (2nd edn). St. Louis, Mosby Year Book, Inc., 1993; pp. 59-78.

15. Katzenstein ALA, Askin FB. Idiopathic interstitial pneumonia/idiopathic pulmonary fibrosis. In: Katzenstein ALA, Askin FB, eds. Surgical Pathology of Nonneoplastic Lung Disease (2nd edn). Philadelphia, WB Sanders Co., 1990; pp. 58-96.

16. Venge P. Human eosinophil granule proteins: structure, function and release. In: Smith $\mathrm{H}$, Cok $\mathrm{RH}$, eds. The handbook of immunopharmacology: immunopharmacology of eosinophils. London, Academic Press, 1993; pp. 43-55.

17. Shijubo N, Imai K, Nakanishi F, Yachi A, Abe S. Elevated concentrations of circulating ICAM-1 in far advanced and miliary tuberculosis. Am Rev Respir Dis, 1993; 148: 1298-1301.

18. Hållgren R, Samuelsson T, Venge P, Modig J. Eosinophil activation in the lung is related to lung damage in adult respiratory distress syndrome. Am Rev Respir Dis 1987; 135: 639-642.

19. Hållgren R, Bjermer L, Lundgren R, Venge P. The eosinophil component of the alveolitis in idiopathic pulomnary fibrosis: signs of eosinophil activation in the lung are related to impaired lung function. Am Rev Respir Dis, 1989; 139: 373-377. 